\title{
Indikasjoner for kryopreservering og autotransplantasjon av eggstokkvev
}

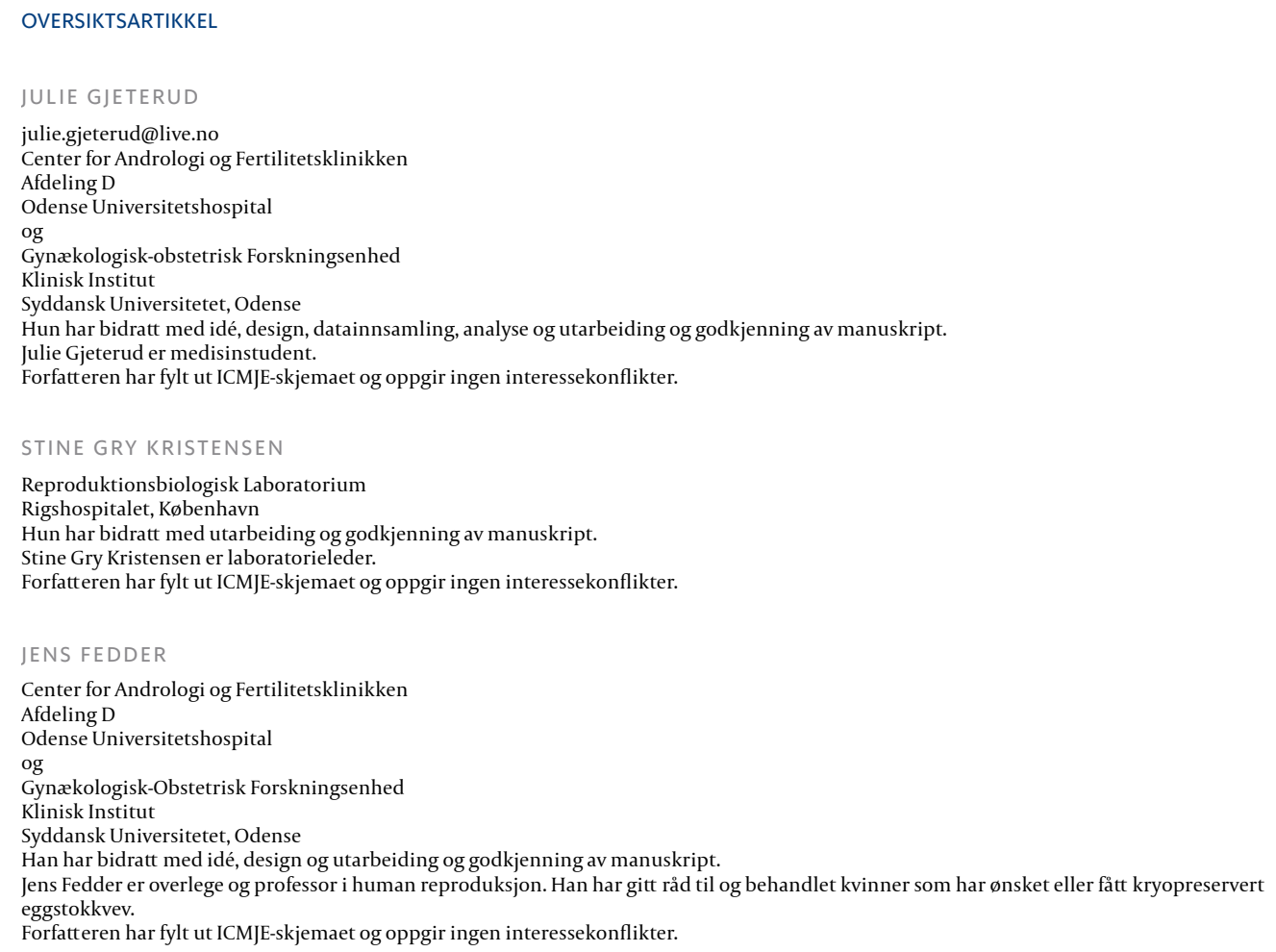

BAKGRUNN

Kryopreservering og autotransplantasjon av eggstokkvev som fertilitetsbevarende behandling tilbys prepubertale jenter og kvinner med høy risiko for å utvikle prematur ovarial insuffisiens i over 20 forskjellige land. Hovedkriteriene for å tilby pasienter denne behandlingen er omdiskuterte. Formålet med artikkelen er å redegjøre for anvendte indikasjoner for kryopreservering og autotransplantasjon av eggstokkvev.

KUNNSKAPSGRUNNLAG

Denne oversiktsartikkelen er basert på litteratursøk i databasene Embase og Medline avgrenset til artikler publisert fra og med 2010.

RESULTATER

Totalt tolv artikler ble inkludert, med diagnoser på 1947 pasienter i alderen o-44 år og 820 pasienter under 18 år. De hyppigste indikasjonene for kryopreservering av eggstokkvev var brystkreft (694 av 1947,36\%) og lymfom (416 av $1947,21 \%$ ). Samlet sett utgjorde maligne sykdommer $86 \%$. Hos pasienter under 18 år var maligne nevrologiske sykdommer (166 av 820, $20 \%$ ), leukemi (156 av 820, $19 \%$ ), sarkomer (125 av 820, 15\%) og benigne hematologiske sykdommer (124 av 820, 15\%) de vanligste indikasjonene. Hos pasienter under 18 år var $26 \%$ av indikasjonene benigne sykdommer. De hyppigste indikasjonene for autotransplantasjon av eggstokkvev var lymfom (74 av 196, 38\%) og brystkreft (53 av 196, 27\%).

FORTOLKNING

Hyppigheten av indikasjonene er i samsvar med forekomsten av sykdommene, men ytterligere erfaringer er nødvendig for å forbedre retningslinjene for behandlingen. Risikoen for autotransplantasjon av maligne celler og stråleskader bør tas i betraktning når man vurderer hvilke pasienter som bør tilbys behandling.

Kryopreservering og autotransplantasjon av eggstokkvev er en fertilitetsbevarende behandling som tilbys prepubertale jenter og kvinner i reproduktiv alder som har risiko for å utvikle prematur ovarial insuffisiens (1) $)$. Behandlingen tilbys ved spesialiserte sentre i over 20 forskjellige land (므). I mange land tilbys fjerning av eggstokkvev ved flere sentre, mens kryopreservering, oppbevaring og autotransplantasjon hovedsakelig foregår ved utvalgte sentre $(3,4$.). 
En av de hyppigste årsakene til prematur ovarial insuffisiens er gonadotoksisk behandling - kjemoterapi og strålebehandling under kreftbehandling. Eggstokkene er særlig sensitive for alkylerende preparater som syklofosfamid, busulfan, dakarbazin og prokarbazin $(5, \underline{6})$. Pasienter som skal gjennomgå en hematopoetisk stamcelletransplantasjon, har en særlig høy risiko for å utvikle prematur ovarial insuffisiens grunnet kondisjoneringsregimet, som består av høydosebehandling med alkylerende stoffer og helkroppsbestråling (5). Andre årsaker til prematur ovarial insuffisiens er benigne hematologiske sykdommer, autoimmune tilstander og genetiske tilstander, som i seg selv eller i kraft av den påkrevde behandling (cytostatika eller stamcelletransplantasjon) øker risikoen for prematur ovarial insuffisiens.

Reproduksjonsevnen kan bevares ved kryopreservering av eggceller, fosteranlegg eller eggstokkvev. Hvilken metode man velger, er avhengig av pasientens alder, risiko for prematur ovarial insuffisiens og hvor raskt behandlingen må begynne (.7). For prepubertale jenter og kvinner hvor behandling må igangsettes raskt, er kryopreservering av eggstokkvev den eneste muligheten for å bevare fruktbarheten, men spesifikke kriterier må brukes for seleksjon av pasienter (ㅁ․,9).

Eggstokkvev blir høstet laparoskopisk ved å ta ut den ene eggstokken eller resektater av en eller begge eggstokker. Barkvevet blir deretter fryst ned i små fragmenter. Hvis pasienten etter avsluttet behandling er i remisjon for sin tilstand, og har utviklet prematur ovarial insuffisiens, kan eggstokkvevet autotransplanteres til den gjenværende eggstokken eller til bekkenveggen. Ved gjenopprettelse av den endokrine funksjonen har kvinnen en mulighet for å bli gravid spontant eller ved assistert befruktning. Autotransplantasjon av nedfryst eggstokkvev er rapportert fra 21 forskjellige land og utgjorde i 2018 totalt 360 autotransplantasjoner

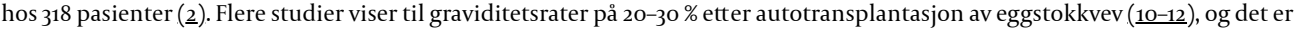
rapportert over 130 levendefødte barn etter autotransplantasjon av eggstokkvev på verdensplan $(\underline{2}, \underline{13})$.

I de nordiske landene har man valgt ulike prinsipper for organisering av kryopreservering av eggstokkvev. I Sverige og Finland er prosedyren regional, mens den i Danmark og Norge er sentralisert på et nasjonalt nivå (14.). I Norge har fertilitetsbevarende kryopreservering av eggstokkvev vært godkjent siden 2004, og behandlingen er sentralisert til Oslo universitetssykehus, som har landsdekkende funksjon for kryopreservering, oppbevaring og autotransplantasjon av eggstokkvev (15, 16). Ved Oslo universitetssykehus har 236 pasienter fått kryopreservert eggstokkvev, og det er utført 30 autotransplantasjoner siden oppstarten i 2004 til og med 2020, hvor syv av pasientene lyktes å bli gravide og det ble født åtte barn (T. Tanbo, personlig meddelelse, mars 2021).

Hovedkriteriene for å tilby pasienter kryopreservering og autotransplantasjon av eggstokkvev er fortsatt omdiskuterte, og formålet med denne studien var derfor å belyse nærmere hvilke pasienter som tilbys denne behandlingen.

\section{Kunnskapsgrunnlag}

Vi søkte i databasene Embase og Medline med emneordene «cryopreservation», «transplantation» og «ovary» samt fritekstordene "cryopreservation", "transplantation», "ovary", "fertility preservation", "cryopreserved ovarian tissue» og "ovarian tissue cryopreservation» i ulike kombinasjoner (se appendiks 1). Søket ble avsluttet 16.6.2021 og var avgrenset til artikler publisert etter 1.1.2010. Totalt 511 artikler ble gjennomgått. Figur 1 viser et flytdiagram over litteratursøket.

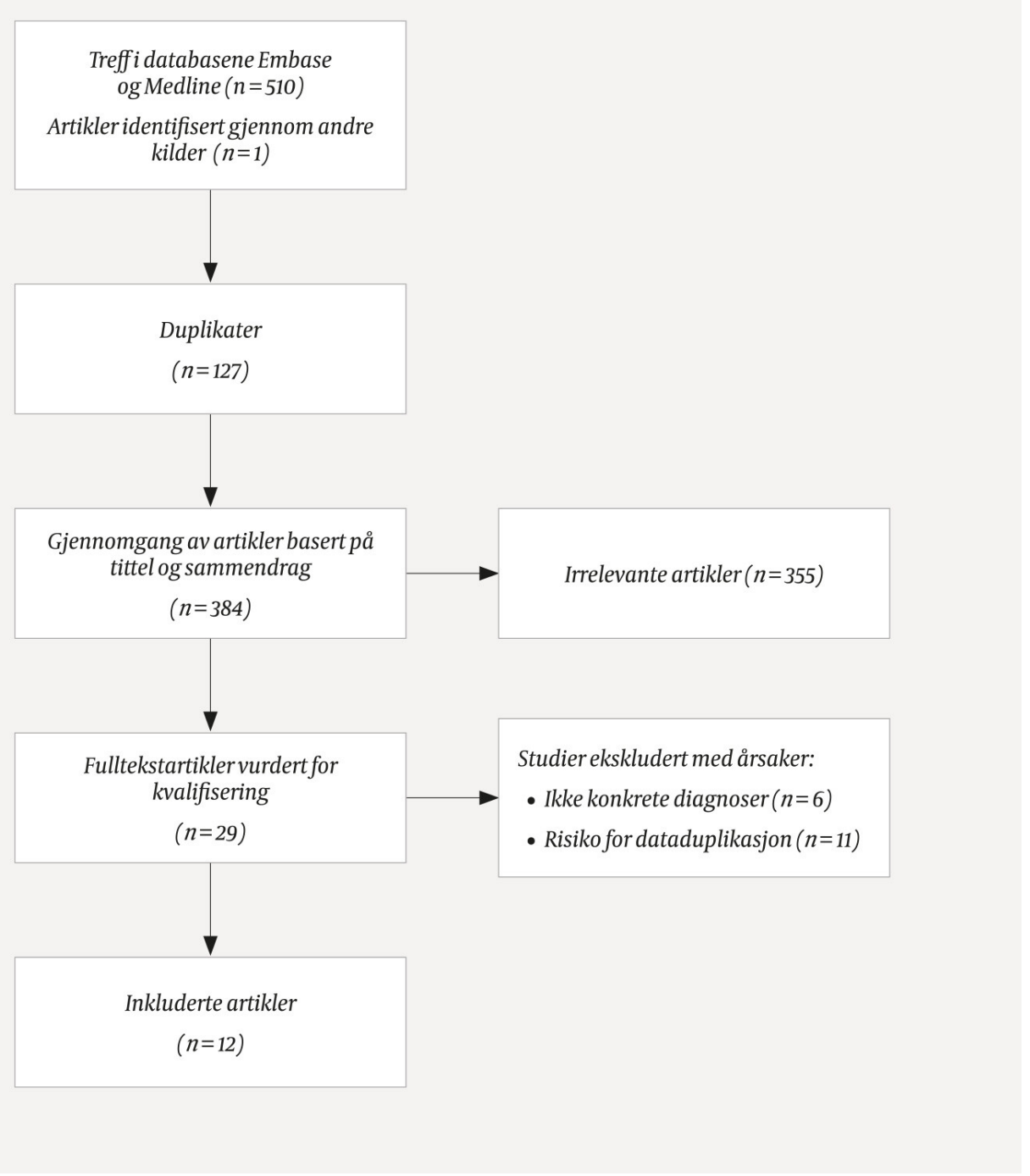


Figur 1 Flytdiagram over litteratursøk. Søket ble avsluttet 16.6.2021 og var avgrenset til artikler publisert etter 1.1.2010. Tittel og sammendrag ble vurdert i 384 artikler for å finne studier med indikasjoner for kryopreservering og/eller

autotransplantasjon av eggstokkvev. Dyreforsøk og studier som ikke presenterte konkrete diagnoser, og hvor indikasjoner ikke var sentralt i sammendraget, ble ekskludert. Ikke-engelskspråklige artikler $(n=1)$, artikler som kun var tilgjengelige som konferansebidrag $(n=21)$, og artikler som biblioteket ikke hadde fullteksttilgang til $(n=2)$, ble ekskludert. Casestudier ble ekskludert for å redusere risikoen for dataduplikasjon. Alle artikkelforfatterne har lest sammendragene, mens den endelige utvelgelsen er gjort av Gjeterud og Fedder.

Totalt 29 artikler ble lest i fulltekst. 17 artikler ble ekskludert pga. mangel på konkrete diagnoser eller risiko for dataduplikasjon, herunder også systematiske oversikter og metaanalyser (se appendiks 2). Noen oversiktsartikler hadde tatt utgangspunkt i tidligere publiserte studier og i tillegg presentert resultater fra egne studier. Vi inkluderte kun rene primærstudier med diagnoseangivelser. Etter eksklusjon ble 12 artikler inkludert (tabell 1) (3, 12, 15, 17-25).

\section{Tabell 1}

Oversikt over inkluderte studier med spesifiserte indikasjoner for kryopreservering og autotransplantasjon av eggstokkvev.

\begin{tabular}{|c|c|c|c|c|c|c|}
\hline Referanse & $\begin{array}{l}\text { Kryopreservering, } \\
\text { antall pasienter } \\
\text { (o-44 år) }\end{array}$ & $\begin{array}{l}\text { Hyppigste } \\
\text { diagnoser for } \\
\text { kryopreservering } \\
\text { (o-44 år) }\end{array}$ & $\begin{array}{l}\text { Autotransplantasjon, } \\
\text { antall pasienter }\end{array}$ & $\begin{array}{l}\text { Hyppigste } \\
\text { diagnoser for } \\
\text { autotransplantasjon }\end{array}$ & $\begin{array}{l}\text { Kryopreservering, } \\
\text { antall pasienter } \\
\text { (<18 år) }\end{array}$ & $\begin{array}{l}\text { Hyppigste } \\
\text { diagnoser for } \\
\text { kryopreservering } \\
\text { (<18 år) }\end{array}$ \\
\hline $\begin{array}{l}\text { Jadoul et } \\
\text { al., } 2017 \\
(12)\end{array}$ & 545 & $\begin{array}{l}\text { Lymfom }(n=127) \text {, } \\
\text { benign/borderline } \\
\text { ovarialtumor ( } n= \\
95), \text { brystkreft ( } n \\
=94)\end{array}$ & $(21)^{1}$ & & & \\
\hline $\begin{array}{l}\text { Tanbo et } \\
\text { al., } 2015 \\
(15)\end{array}$ & 164 & $\begin{array}{l}\text { Brystkreft }(n= \\
66), \text { lymfom }(n= \\
41), \text { sarkom }(n= \\
24)\end{array}$ & 2 & Lymfom $(n=2)$ & & \\
\hline $\begin{array}{l}\text { Jadoul et } \\
\text { al., } 2010 \\
(17)\end{array}$ & & & & & 58 & $\begin{array}{l}\text { Sarkom }(n=14), \\
\text { leukemi }(n=14), \\
\text { lymfom }(n=12)\end{array}$ \\
\hline $\begin{array}{l}\text { Poirot et } \\
\text { al., } 2019 \\
(18)\end{array}$ & & & & & 418 & $\begin{array}{l}\text { Neuroblastom ( } n \\
=93) \text {, benigne } \\
\text { hematologiske } \\
\text { sykdommer ( } n= \\
82) \text {, leukemi ( } n= \\
76)\end{array}$ \\
\hline $\begin{array}{l}\text { Lotz et al., } \\
2020 \text { (19) }\end{array}$ & & & & & 102 & $\begin{array}{l}\text { Lymfom }(n=34) \\
\text { leukemi }(n=20) \\
\text { sarkom }(n=17)\end{array}$ \\
\hline $\begin{array}{l}\text { Kristensen } \\
\text { et al., } 2021 \\
(20)\end{array}$ & 944 & $\begin{array}{l}\text { Brystkreft ( } n= \\
456), \text { lymfom ( } n= \\
\text { 170), gynekologisk } \\
\text { malignitet ( } n= \\
90)\end{array}$ & 104 & $\begin{array}{l}\text { Brystkreft }(n=40) \text {, } \\
\text { lymfom }(n=23), \\
\text { gynekologisk } \\
\text { malignitet }(n=12)\end{array}$ & 242 & $\begin{array}{l}\text { Sarkom }(n=52) \\
\text { leukemi }(n=46) \\
\text { lymfom }(n=38)\end{array}$ \\
\hline $\begin{array}{l}\text { Gracia et } \\
\text { al., } 2012 \\
(21)\end{array}$ & 21 & $\begin{array}{l}\text { Leukemi }(n=4), \\
\text { brystkreft }(n=3) \text {, } \\
\text { lymfom }(n=3) \\
\text { sarkom }(n=3)\end{array}$ & $(13)^{1}$ & & & \\
\hline $\begin{array}{l}\text { Lotz et al., } \\
2016 \text { (22) }\end{array}$ & 147 & $\begin{array}{l}\text { Lymfom }(n=47) \text {, } \\
\text { brystkreft }(n=37) \text {, } \\
\text { maligne } \\
\text { gynekologiske } \\
\text { sykdommer }(n= \\
22)\end{array}$ & & & & \\
\hline $\begin{array}{l}\text { Oktay et } \\
\text { al., } 2010 \\
(23)\end{array}$ & 59 & $\begin{array}{l}\text { Lymfom }(n=18) \text {, } \\
\text { brystkreft }(n=13) \text {, } \\
\text { leukemi }(n=9)\end{array}$ & 3 & $\begin{array}{l}\text { Brystkreft }(n=1) \\
\text { lymfom }(n=1) \\
\text { endometriose }(n=1)\end{array}$ & & \\
\hline $\begin{array}{l}\text { Hoekman } \\
\text { et al., } \\
2020 \text { (24) }\end{array}$ & 69 & $\begin{array}{l}\text { Brystkreft }(n=25), \\
\text { sarkom }(n=17) \\
\text { lymfom }(n=9)\end{array}$ & 7 & $\begin{array}{l}\text { Brystkreft }(n=3), \\
\text { lymfom }(n=3), \\
\text { sarkom }(n=1)\end{array}$ & & \\
\hline $\begin{array}{l}\text { Dittrich et } \\
\text { al., } 2015 \\
\text { (3) }\end{array}$ & & & 20 & $\begin{array}{l}\text { Lymfom }(n=11), \\
\text { brystkreft }(n=4), \\
\text { gastrointestinal } \\
\text { malignitet }(n=3)\end{array}$ & & \\
\hline $\begin{array}{l}\text { Shapira et } \\
\text { al., } 2020 \\
(25)\end{array}$ & & & 60 & $\begin{array}{l}\text { Lymfom }(n=34) \text {, } \\
\text { benigne sykdommer } \\
(n=9) \text {, leukemi }(n= \\
\text { 5), brystkreft }(n=5)\end{array}$ & & \\
\hline
\end{tabular}

${ }^{1}$ Antall oppført i parentes er ikke inkludert i den aktuelle studien pga. risiko for dataduplikasjon eller mangel på konkret diagnose.

Som et resultat av at noen artikler inkluderer pasienter i alle aldre uten at det oppgis konkrete diagnoser for de ulike aldersgruppene, er det et overlapp på omkring go pasienter mellom den aktuelle studiens inndeling av pasienter i kategoriene "pasienter 0-44 år» ( $n=1947)$ og "pasienter under 18 år» $(n=820)$.

\section{Resultater}


Resultatene for kryopreservering i alderen o-44 år er vist i tabell 2, første kolonne (12, 15, 20-24). Samlet viser studiene diagnoser for totalt 1947 pasienter i aldersspennet fra seks måneder (1ㅡ) til 44 år (23). Ser man på oppgitte enkeltdiagnoser, var brystkreft den hyppigste indikasjonen for kryopreservering av eggstokkvev (694 av 1 947,36\%), etterfulgt av lymfom (416 av $1947,21 \%$ ). I Norge, Danmark, Nederland og USA var brystkreft den vanligste indikasjonen $(\mathbf{1 5}, \underline{20}, \underline{21}, \mathbf{2 3}, \underline{24}$.), mens lymfom var den vanligste i Belgia og Tyskland $(\underline{\mathbf{1 2}}, \underline{22})$. Samlet sett utgjorde maligne sykdommer $86 \%$ av indikasjonene og benigne sykdommer $13 \%$. De resterende var andre, uklassifiserte indikasjoner.

\section{Tabell 2}

Anvendte indikasjoner for kryopreservering av eggstokkvev fordelt på pasienter o-44 år og pasienter under 18 år samt anvendte indikasjoner for autotransplantasjon av eggstokkvev. En mindre gruppe pasienter kan fremgå både i kolonnen o-44 år og <18 år. Tallene er fra studier publisert f.o.m. 2010. Antall (prosentandel av totalt antall).

\begin{tabular}{|c|c|c|c|}
\hline \multirow[t]{2}{*}{ Anvendte indikasjoner } & \multicolumn{2}{|l|}{ Kryopreservering } & \multirow[t]{2}{*}{ Autotransplantasjon } \\
\hline & Pasienter 0-44 år & Pasienter $<18$ år & \\
\hline Brystkreft & $694(36)$ & & $53(27)$ \\
\hline Lymfomer & $416(21)$ & $94(12)$ & $74(38)$ \\
\hline Hodgkins lymfom & $61(3)$ & & 37 (19) \\
\hline Non-Hodgkins lymfom & $16(1)$ & & $14(7)$ \\
\hline Uklassifiserte lymfomer & $339(17)$ & $94(12)$ & $23(12)$ \\
\hline \multicolumn{4}{|l|}{ Maligne hematologiske sykdommer } \\
\hline Leukemi, myelodysplastisk syndrom & $112(6)$ & $156(19)$ & $10(5)$ \\
\hline Andre & & $11(1)$ & \\
\hline Sarkomer & $149(8)$ & $125(15)$ & $11(6)$ \\
\hline Maligne gynekologiske sykdommer & $154(8)$ & $3(0,4)$ & $17(9)$ \\
\hline Maligne nevrologiske sykdommer & $62(3)$ & $166(20)$ & $3(2)$ \\
\hline Nevroblastom & $1(0)$ & $104(13)$ & \\
\hline Kreft i sentralnervesystemet & $61(3)$ & $62(7)$ & \\
\hline Maligne gastroinstestinale sykdommer & $53(3)$ & & $7(4)$ \\
\hline \multicolumn{4}{|l|}{ Andre } \\
\hline Wilms' tumor & & $19(2)$ & \\
\hline Benigne hematologiske sykdommer & $39(2)$ & $124(15)$ & $6(3)$ \\
\hline $\begin{array}{l}\text { Benigne gynekologiske sykdommer, } \\
\text { borderline ovarialtumor }\end{array}$ & $101(5)$ & $32(4)$ & \\
\hline Genetiske sykdommer & $25(1)$ & $5(0,6)$ & $4(2)$ \\
\hline Systemisk sykdom & $55(3)$ & $47(6)$ & $11(6)$ \\
\hline Andre benigne sykdommer & $35(2)$ & $38(5)$ & \\
\hline Andre maligne sykdommer & $10(1)$ & & \\
\hline Andre, uklassifiserte & $42(2)$ & & \\
\hline Total & 1947 & 820 & 196 \\
\hline
\end{tabular}

Tabell 2 andre kolonne viser de hyppigste indikasjonene for kryopreservering av eggstokkvev hos pasienter under 18 år med

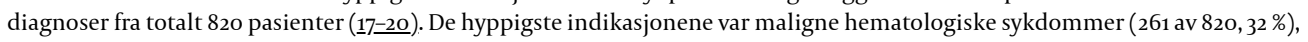
primært leukemi (156 av 820, 19\%), maligne nevrologiske sykdommer (166 av 820, $20 \%$ ), sarkomer (125 av 820, $15 \%$ ) og benigne hematologiske sykdommer (124 av 820, $15 \%$ ). Samlet sett utgjorde maligne sykdommer $74 \%$ og benigne sykdommer $26 \%$ i denne aldersgruppen.

INDIKASJONER FOR AUTOTRANSPLANTASJON

Resultatene fra de inkluderte studiene er vist i tabell 2 (3, 15, 20, 23-25). Disse rapporterte totalt 196 pasienter som hadde fått utført autotransplantasjon av eggstokkvev. Blant disse var lymfom ( 74 av 196, $38 \%$ ) den hyppigste indikasjonen, etterfulgt av brystkreft (53 av 196, $27 \%$ ). Denne fordelingen var utpreget i studiene fra Belgia, USA, Israel og Tyskland (3, 25). I studien fra Danmark var brystkreft hyppigste indikasjon $(\underline{20})$ (tabell 1 ).

\section{Diskusjon}

Denne litteraturgjennomgangen viser at brystkreft og lymfom til nå har vært de vanligste indikasjonene for kryopreservering og autotransplantasjon av eggstokkvev. Dette kan forklares med at disse kreftdiagnosene er blant de vanligste i verden hos pasienter under 40 år $(\underline{26})$, og at risikoen for autotransplantasjon av maligne celler ved disse diagnosene anses for å være minimal (27). For pasienter under 20 år er leukemi, kreft i sentralnervesystemet og lymfom blant de vanligste kreftdiagnosene på verdensplan (므), noe som videre kan forklare hvorfor disse diagnosene er hyppige indikasjoner for kryopreservering i denne aldersgruppen. I tillegg var andelen benigne sykdommer høyest hos pasienter under 18 år (indikasjon hos én av fire pasienter). 
Litteraturgjennomgangen viser at fordelingen av de forskjellige diagnosene med hensyn til kryopreservering og autotransplantasjon varierer mellom ulike land, noe som tyder på manglende konsensus omkring hvilke pasienter som bør tilbys behandlingen. Dette skyldes primært manglende evidens for hvilke pasienter som har mest nytte av den. Det er fortsatt uklart hvor mange pasienter som utvikler prematur ovarial insuffisiens etter en gonadotoksisk behandling, og hvem som har mest nytte av nedfryst eggstokkvev. Tilbud om fertilitetsbevarende behandling er avhengig av en individuell vurdering av hver enkelt pasients sykdom, reproduktive bakgrunn og personlige ønsker, hvilket kan variere fra land til land og mellom sentre. I Danmark autotransplanteres eggstokkvev bl.a. til kvinner for å forbedre lav eggstokkreserve, uten at kvinnen nødvendigvis har opplevd prematur ovarial insuffisiens. Videre utføres også autotransplantasjon for å reetablere eggstokkenes naturlige hormonproduksjon (므). Dette er imidlertid et ressurskrevende alternativ til vanlig hormonerstatningsterapi.

I en norsk originalartikkel publisert av Johansen og medarbeidere i 2018 ble det rapportert at 20 av 74 pasienter (27\%) utviklet

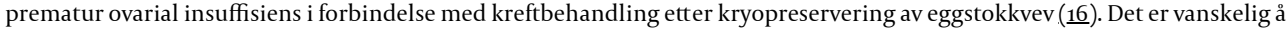
forutsi nøyaktig hvilke pasienter som vil utvikle prematur ovarial insuffisiens etter gonadotoksisk behandling. En dansk studie viste at $72 \%$ av kvinnene som prøvde å bli gravide etter kreftbehandling og kryopreservering av eggstokkvev, lyktes $(\underline{28})$. Dette kan til dels forklare hvorfor bruksraten, dvs. antallet pasienter som får autotransplantert eggstokkvev, er relativt lav - omkring $5 \%$ (4, 15, 25) - til tross for den store mengden eggstokkvev som fryses ned. Langtidsstudier er nødvendige for å avklare risikoen for prematur ovarial insuffisiens og bruksratene hos disse pasientene.

KONTRAINDIKASJONER

Flere studier har analysert risikoen for å autotransplantere maligne celler som potensielt foreligger i nedfryst eggstokkvev, og risikoen for tilbakefall av primærtumor (27).). Det er rapportert gode resultater etter behandling for brystkreft, lymfom og sarkomer, hvor risikoen for tilbakefall ved autotransplantasjon anses som minimal (27.). Autotransplantasjon av eggstokkvev fra pasienter med akutt leukemi eller eggstokkreft er derimot beskrevet som risikofylt (209-31). Tolv kvinner med leukemi har fått

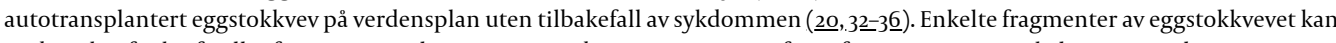
undersøkes for kreftceller før autotransplantasjon, men det er ingen garanti for at fragmentene som skal autotransplanteres, er kreftfrie, da dette på nåværende tidspunkt ikke kan testes med de tilgjengelige analysemetodene. Blant de 360 autotransplantasjonene på verdensbasis er det rapportert om ett tilfelle med tilbakefall av granulosacelletumor ved autotransplantasjon av eggstokkvev (31). Eggstokkreft er imidlertid en sjelden indikasjon for kryopreservering, da man er tilbakeholden med autotransplantasjon ved denne diagnosen (27.7).

Strålebehandling kan påvirke blodtilførselen i bekkenet og føre til et atrofisk slimhinnelag og redusert funksjon av livmormuskelen, som igjen kan komplisere en potensiell graviditet (37.). Autotransplantasjon av eggstokkvev hos pasienter som har fått strålebehandling mot bekkenet, gir derfor usikker effekt, og er i enkelte tilfeller kontraindisert (37.). Shapira og medarbeidere rapporterte at en pasient behandlet for kolorektalkreft med stråledoser opp mot 45 Gy fødte for tidlig, mens pasienter som fikk helkroppsbestråling med doser under $20 \mathrm{~Gy}$, fødte til tiden uten komplikasjoner. Ingen pasienter med livmorshalskreft ble gravide (25). Dittritch og medarbeidere viste lignende resultater for pasienter behandlet for analkreft (3). Her fikk pasientene en stråledose på 50 Gy, noe som tilsvarer en organdose på over zo Gy mot livmoren. Blant fire kvinner med analkreft var det ingen som ble gravide etter autotransplantasjon, til tross for regelmessig menstruasjon (3).

SVAKHETER

En stor andel artikler ble ekskludert på grunn av mangel på konkrete diagnoser eller risiko for dataduplikasjon, og vår studie viser derfor ikke en komplett oversikt over pasienter behandlet med kryopreservering og autotransplantasjon av eggstokkvev som er beskrevet i litteraturen. Ut over dette har det ikke vært mulig å beskrive indikasjonene helt presist, da de inkluderte artiklene ikke benytter samme diagnoseinndeling. En mindre andel pasienter finnes både i kategorien "pasienter o-44 år» og "pasienter under 18 år», da det er utfordrende å unngå dataduplikasjon, men inndelingen gir likevel et inntrykk av forskjellene mellom de to aldersgruppene.

KONKLUSJON

Denne litteraturgjennomgangen viser at brystkreft og lymfom har vært de hyppigste indikasjonene for kryopreservering og autotransplantasjon av eggstokkvev. Langtidserfaring og flere resultater fra pasienter som har fått autotransplantert eggstokkvev, vil forhåpentligvis resultere i enda bedre retningslinjer for hvilke pasienter som har størst utbytte av behandlingen, og mer konsensus i feltet.

Forfatterne takker professor emeritus Tom Tanbo ved Reproduksjonsmedisinsk avdeling ved Oslo universitetssykehus for opplysninger om kryopreservering og autotransplantasjon av eggstokkvevi Norge.

Artikkelen erfagfellevurdert.

HOVEDFUNN

Brystkreft og lymfom var de hyppigste indikasjonene for kryopreservering og autotransplantasjon av eggstokkvev.

Leukemi, maligne nevrologiske sykdommer, sarkomer og benigne hematologiske sykdommer var de hyppigste indikasjonene for kryopreservering av eggstokkvev hos pasienter under 18 år.

Hos pasienter under 18 år var $26 \%$ av indikasjonene benigne sykdommer.

Indikasjonene varierte mellom forskjellige land og sentre.

\section{REFERENCES}

1. Veileder i gynekologi: Prematur ovarialinsuffisiens. Oslo: Norsk Gynekologisk forening, 2021

https://www.legeforeningen.no/foreningsledd/fagmed/norsk-gynekologisk-forening/veiledere/veileder-i-gynekologi/ Lest 6.3.2021.

2. Gellert SE, Pors SE, Kristensen SG et al. Transplantation of frozen-thawed ovarian tissue: an update on worldwide activity published in peerreviewed papers and on the Danish cohort. J Assist Reprod Genet 2018; 35: 561-70. [PubMed][CrossRef]

3. Dittrich R, Hackl J, Lotz L et al. Pregnancies and live births after 20 transplantations of cryopreserved ovarian tissue in a single center. Fertil Steril 2015; 103: 462-8. [PubMed][CrossRef]

4. Rosendahl M, Schmidt KT, Ernst E et al. Cryopreservation of ovarian tissue for a decade in Denmark: a view of the technique. Reprod Biomed Online 2011; 22: 162-71. [PubMed][CrossRef]

5. Stensvold E, Magelssen H, Oskam IC. Fertilitetsbevarende tiltak hos jenter og unge kvinner med kreft. Tidsskr Nor Legeforen 2011;131:1429-32. [PubMed][CrossRef] 
6. Dansk Fertilitetsselskab. Fertilitetsbevaring ved malign sygdom. https://fertilitetsselskab.dk/kliniske-guidelines-i-brug/ Lest 10.3.2021.

7. Dolmans MM, Donnez J. Fertility preservation in women for medical and social reasons: Oocytes vs ovarian tissue. Best Pract Res Clin Obstet Gynaecol 2021; 70: 63-80. [PubMed][CrossRef]

8. Storeng R, Abyholm T, Tanbo T. Kryopreservering av ovarialvev. Tidsskr Nor Laegeforen 2007; 127: 1045-8. [PubMed]

9. Wallace WH, Smith AG, Kelsey TW et al. Fertility preservation for girls and young women with cancer: population-based validation of criteria for ovarian tissue cryopreservation. Lancet Oncol 2014; 15: 1129-36. [PubMed][CrossRef]

10. Jensen AK, Kristensen SG, Macklon KT et al. Outcomes of transplantations of cryopreserved ovarian tissue to 41 women in Denmark. Hum Reprod 2015; 30: 2838-45. [PubMed][CrossRef]

11. Pacheco F, Oktay K. Current success and efficiency of autologous ovarian transplantation: A meta-analysis. Reprod Sci 2017; 24: 1111-20. [PubMed] [CrossRef]

12. Jadoul P, Guilmain A, Squifflet J et al. Efficacy of ovarian tissue cryopreservation for fertility preservation: lessons learned from 545 cases. Hum Reprod 2017;32: 1046-54. [PubMed][CrossRef]

13. Donnez J, Dolmans MM. Fertility preservation in women. N Engl J Med 2017; 377: 1657-65. [PubMed][CrossRef]

14. Rodriguez-Wallberg KA, Tanbo T, Tinkanen $\mathrm{H}$ et al. Ovarian tissue cryopreservation and transplantation among alternatives for fertility preservation in the Nordic countries - compilation of 20 years of multicenter experience. Acta Obstet Gynecol Scand 2016; 95: 1015-26. [PubMed] [CrossRef]

15. Tanbo T, Greggains G, Storeng R et al. Autotransplantation of cryopreserved ovarian tissue after treatment for malignant disease - the first Norwegian results. Acta Obstet Gynecol Scand 2015; 94: 937-41. [PubMed][CrossRef]

16. Johansen MS, Tanbo TG, Oldereid NB. Fertilitet etter kryopreservering av ovarialvev ved kreftbehandling. Tidsskr Nor Legeforen 2018; 138. doi: 10.4045/tidsskr.17.0719. [PubMed][CrossRef]

17. Jadoul P, Dolmans MM, Donnez J. Fertility preservation in girls during childhood: is it feasible, efficient and safe and to whom should it be proposed? Hum Reprod Update 2010; 16: 617-30. [PubMed][CrossRef]

18. Poirot C, Brugieres L, Yakouben K et al. Ovarian tissue cryopreservation for fertility preservation in 418 girls and adolescents up to 15 years of age facing highly gonadotoxic treatment. Twenty years of experience at a single center. Acta Obstet Gynecol Scand 2019; 98: 630-7. [PubMed] [CrossRef]

19. Lotz L, Barbosa PR, Knorr C et al. The safety and satisfaction of ovarian tissue cryopreservation in prepubertal and adolescent girls. Reprod Biomed Online 2020; 40: 547-54. [PubMed][CrossRef]

20. Kristensen SG, Wakimoto Y, Colmorn LB et al. Use of cryopreserved ovarian tissue in the Danish fertility preservation cohort. Fertil Steril 2021; 116: 1098-106. [PubMed][CrossRef]

21. Gracia CR, Chang J, Kondapalli L et al. Ovarian tissue cryopreservation for fertility preservation in cancer patients: successful establishment and feasibility of a multidisciplinary collaboration. J Assist Reprod Genet 2012; 29: 495-502. [PubMed][CrossRef]

22. Lotz L, Maktabi A, Hoffmann I et al. Ovarian tissue cryopreservation and retransplantation-what do patients think about it? Reprod Biomed Online 2016; 32:394-400. [PubMed][CrossRef]

23. Oktay K, Oktem O. Ovarian cryopreservation and transplantation for fertility preservation for medical indications: report of an ongoing experience. Fertil Steril 2010; 93: 762-8. [PubMed][CrossRef]

24. Hoekman EJ, Louwe LA, Rooijers M et al. Ovarian tissue cryopreservation: Low usage rates and high live-birth rate after transplantation. Acta Obstet Gynecol Scand 2020; 99: 213-21. [PubMed][CrossRef]

25. Shapira M, Dolmans MM, Silber S et al. Evaluation of ovarian tissue transplantation: results from three clinical centers. Fertil Steril 2020; 114 388-97. [PubMed][CrossRef]

26. World Health Organization (WHO). Cancer today. https://gco.iarc.fr/ Lest 20.5.2021.

27. Dolmans MM, Masciangelo R. Risk of transplanting malignant cells in cryopreserved ovarian tissue. Minerva Ginecol 2018; 70: 436-43. [PubMed]

28. Schmidt KT, Nyboe Andersen A, Greve T et al. Fertility in cancer patients after cryopreservation of one ovary. Reprod Biomed Online 2013; 26: 272-9. [PubMed][CrossRef]

29. Dolmans MM, Marinescu C, Saussoy P et al. Reimplantation of cryopreserved ovarian tissue from patients with acute lymphoblastic leukemia is potentially unsafe. Blood 2010; 116: 2908-14. [PubMed][CrossRef]

30. Rosendahl M, Andersen MT, Ralfkiær E et al. Evidence of residual disease in cryopreserved ovarian cortex from female patients with leukemia. Fertil Steril 2010; 94: 2186-9o. [PubMed][CrossRef]

31. Stern CJ, Gook D, Hale LG et al. Delivery of twins following heterotopic grafting of frozen-thawed ovarian tissue. Hum Reprod 2014; 29: 1828. [PubMed][CrossRef]

32. Meirow D, Ra'anani H, Shapira M et al. Transplantations of frozen-thawed ovarian tissue demonstrate high reproductive performance and the need to revise restrictive criteria. Fertil Steril 2016; 106: 467-74. [PubMed][CrossRef]

33. Shapira M, Raanani H, Barshack I et al. First delivery in a leukemia survivor after transplantation of cryopreserved ovarian tissue, evaluated for leukemia cells contamination. Fertil Steril 2018; 109:48-53. [PubMed][CrossRef]

34. Silber SJ, DeRosa M, Goldsmith S et al. Cryopreservation and transplantation of ovarian tissue: results from one center in the USA. J Assist Reprod Genet 2018; 35: 2205-13. [PubMed][CrossRef]

35. Sonmezer M, Ozkavukcu S, Sukur YE et al. First pregnancy and live birth in Turkey following frozen-thawed ovarian tissue transplantation in a patient with acute lymphoblastic leukemia who underwent cord blood transplantation. J Assist Reprod Genet 2020; 37: 2033-43. [PubMed] [CrossRef]

36. Poirot C, Fortin A, Dhédin N et al. Post-transplant outcome of ovarian tissue cryopreserved after chemotherapy in hematologic malignancies. Haematologica 2019; 104: e360-3. [PubMed][CrossRef]

37. Teh WT, Stern C, Chander S et al. The impact of uterine radiation on subsequent fertility and pregnancy outcomes. BioMed Res Int 2014 ; 2014. doi: 10.1155/2014/482968. [PubMed][CrossRef]

Publisert: 25. oktober 2021. Tidsskr Nor Legeforen. DOI: 10.4045/tidsskr.21.0030

Mottatt 11.1.2021, første revisjon innsendt 15.3.2021, godkjent 27.8.2021.

Publisert under åpen tilgang CC BY-ND. Lastet ned fra tidsskriftet.no 26. april 2023. 